\title{
4
}

\section{Crisis? What Crisis? Norwegian Shipping in the Interwar Period}

On 14 October 1924, the reputable US newspaper, The Washington Post, featured an article on the Norwegian ship Sagatind, where the crew allegedly had ended up in a free-for-all fight after a "wild orgy on contraband cargo." The ship had been floating "aimlessly 40 miles off New York without a helmsman" two days earlier, when 22 representatives from the US Coast Guard vessel Seneca boarded. The Americans found "two sailors asleep in the wheelhouse. Below decks they found the rest of the crew. Some were asleep, some were in their bunks nursing broken bones, and some were staggering about in a stupor. Nearly all were nursing black eyes." ${ }^{\prime}$ According to the newspaper report, the Coast Guard put the crew of 32 in irons, and confiscated the cargo, which consisted of more than 40,000 cases of liquor.

The crew received a heavy-handed welcome by the US authorities, and one mate was beaten so heavily that he lost three teeth and had to be hospitalized after he had tried to stop one of the customs officers from stealing a bottle of whiskey. Following the seizure, Sagatind was anchored off the Statue of Liberty. The illegal cargo was discharged to a Brooklyn

${ }^{1}$ The Washington Post, 141024, 10. 
army base-with around 1000 cases of liquor mysteriously disappearing during the transfer. ${ }^{2}$ It is evident that all the hard work during Prohibition made US officials thirsty.

The owner of Sagatind was AS Reidar, a company controlled by Finn Friis and Carl Otto Lund-the latter a High Court attorney who had served as mayor of Drammen in two periods and as a Member of Parliament from 1916 to 1921 . The vessel had been chartered to an American smuggling syndicate through a French front man, and the ship had also spent large parts of June 1924 on "Rum Row" - the line of smuggling ships anchored just beyond the US maritime limit. Although the Sagatind-debacle received a lot of attention on both sides of the Atlantic, it turned out that the premise for the arrest of the ship had been wrong. The authorities wanted to use the Sagatind as a test case, but the necessary regulation against foreign smuggling ships had not yet been ratified by the Senate.

The missing legal basis created problems for the authorities, as a legal technicality implied that the US Coast Guard had no right to enter the ship 22 miles off the coast. The shipowners considered demanding compensation from the Americans, but after some gentle persuasion the claims were silently shelved. The seamen, on the other hand, entered into a drawn-out battle for damages. While the press reports of the contraband orgy turned out to be an early example of "fake news," the violence was real. However, the perpetrators were the US officials, rather than the seafarers themselves. Indeed, in some Norwegian newspaper articles the innocence — and sobriety — of the Norwegian sailors, and the heavy treatment that they had been given, were emphasized. ${ }^{3}$ The seafarers were adamant that they deserved compensation for the detention and for the manner in which they were treated. Even 10 years after the event, they tried to convince the Norwegian authorities that reparations were justified.

The Sagatind incidence was one of the first examples of Norwegian presence in the less-salubrious part of the shipping sector-and

\footnotetext{
${ }^{2}$ The New York Times, 050225, 5 and Nordisk Tidende, 120225, 4.

${ }^{3}$ For a detailed account of the Sagatind story, see Johansen (1994, 13-23) and for a presentation that is favourable to the crew, see 1ste Mai, 250628, 6. A more sober account-where the crews are neither angels nor devils_ can be found in Arbeiderbladet, 150125, 9. Another good account of the smuggling business in general in this period is Chapters 1-3 of Lawson (2013).
} 
undoubtedly the most publicized. Of course, Sagatind was not the only Norwegian ship engaged in smuggling during the Prohibition era, and it could be tempting to use the smuggling ships as an example of the increasing desperation of Norwegian shipping companies during a period of low activity in the shipping market. However, such an interpretation would be terribly wrong.

Although it has been claimed that the Norwegians had an exceptionally bad reputation with regard to smuggling, there are absolutely no indications that they were overrepresented among smugglers. ${ }^{4}$ In fact, while the interwar period generally is considered a bad period for international trade and shipping, Norwegian shipowners stood out favourably, orchestrated an impressive resurgence and increased their share of the world fleet. More importantly, while they had controlled a fleet of relatively old and outdated ships before 1914 , by the end of the interwar period Norway had succeeded in modernizing the fleet and had the world's youngest and technologically most advanced merchant marine.

In some ways, the interwar period saw Norwegian shipping culture at its best. Shipping companies were forced to look for new market opportunities, and when a viable course had been found, they managed to exploit the desperation of idle Swedish and Danish yards to secure cheap tonnage. Based on a combination of experience, knowledge and willingness to take risk — and helped by the requisite portion of luck - Norwegian shipowners managed to come strengthened out of a difficult period for world shipping.

\section{Between the Wars}

The Great Depression is often the starting point for discussions about the low economic growth of the interwar period, but the Great Depression was both a symptom and a cause of more far-reaching problems in the international economy.

\footnotetext{
${ }^{4}$ For the claim about Norwegian reputation, see for instance Behr (1996). There is limited evidence to support the claim. In 1925, only 10 of the more than 330 smuggling ships in US waters were Norwegian; this 3 per cent share was lower than the Norwegian share of the world fleet; Nordisk Tidende, 050525, 1.
} 
The First World War-at the time referred to as the Great Warbrought an abrupt end to the liberal world economy that had developed in the decades before 1914. Although there had been signs of increased protectionism at the start of the 20th century, the benefits of specialization and division of labour were so large that international trade continued to grow, spurred by a dramatic reduction of transport and other transaction costs. Intercontinental migration flows of more than a million people annually also created substantial demand for shipping before the war.

The breakdown of the world economy during the war, the financial turmoil of the 1920s, the depression of the early 1930s and the sluggish recovery came as a surprise to most of those involved. When the First World War ended, there had been considerable optimism about the demand for transport as individual nations and the world economy itself embarked on the road to recovery. Although the main merchant marines had suffered substantial losses during the war, the enormous expansion of shipbuilding activity, particularly in the United States, meant that the fleet had actually increased marginally relative to its size before the war.

However, neutral Norway had suffered more than most. ${ }^{5}$ The courageous — or foolhardy_employment of the fleet during the hostilities had led to substantial losses. At the end of 1918 the carrying capacity of the Norwegian fleet was around a quarter lower than it had been at the end of 1914. At the same time, there had been a structural shift in the fleet; the sailing ship tonnage had been more than halved, while the steamship fleet lost around 25 per cent. There was a strong increase in the proportion and tonnage of motorships, but from a relatively low starting point. ${ }^{6}$

During the war, the Norwegian merchant marine had developed unfavourably — both in terms of quality and quantity. Many of the additions

\footnotetext{
${ }^{5}$ According to data on the period August 1914-October 1918, in Statistics Norway (1919, 191), three countries had a higher net reduction than Norway (30\%); Germany (44\%), Belgium (48\%) and Greece (47\%). With the exception of Argentina, the fleets increased in all non-European countries for which we have statistics. The US fleet, increasing by more than 2.8 million compensated tons $(154 \%)$, had the highest absolute and relative growth. However, a commonly published overview puts the Norwegian losses $(49.6 \%)$ at the top, followed by Italy and Greece; see Egeland $(1930,18)$; Brækhus $(1934,106)$ or Haaland $(1940,18)$. This is based on gross losses-not taking acquisitions into account.

${ }^{6}$ Calculated on the basis of Statistics Norway $(1919,62)$.
} 
from the war years were relatively old, inefficient ships. Although all capacity was useful during the war boom, Norway's competitive position had deteriorated severely, with the share of the world fleet falling by approximately a quarter-from around 4 per cent to around 3 per cent.

Throughout the war, materials and shipbuilding capacity had been in short supply, and ships that would under other circumstances have been considered inferior, easily found employment. There were also some novel solutions. One innovation was ships made of concrete. When the first large Norwegian-built ship made of concrete was launched in 1917, it was heralded as the ship of the future. The advantage of the concrete ships was that they did not rust and were easy to maintain-the disadvantage was that they for all practical purposes were quite useless outside the harbour, extremely slow and difficult to handle. Less than two years after the launch, the Norwegian Shipowners' Association referred to this "ship of the future" as a "totally unsuccessful vessel" and suggested that it would benefit the fleet if such "surrogate vessels" were removed.

The desperate demand for tonnage also spurred a revival of shipbuilding on the South Coast of Norway. When activity peaked in the spring of 1918 , some 80 yards that had been dormant for decades or engaged only in repair, had commenced the building of new ships. Norwegian owners also ordered almost 150 wooden ships - usually with auxiliary enginesin the United States and Canada. Some of the US contacts turned out to be "frauds," while others used the Norwegian instalments to build up non-existing yards, with little funds left to construct the ships. As the war spread, it became increasingly difficult to acquire new tonnage. In the United States, more than 40 newbuildings for Norwegian account had been confiscated by the authorities after the Americans entered the warthese were all steelships, as even the American authorities had limited interest in the wooden vessels that Norwegians had ordered there. ${ }^{8}$

Although those who fell victim to the confiscation were promised "just compensation" the case dragged on after the war. In 1919 most of the owners saw the return of their paid-in instalments-in total USD34

\footnotetext{
${ }^{7}$ Schreiner $(1963,404-405)$. For a detailed history of the loss-bringing operation of one concretebuilt ships, see Langfeldt (1980, 76-79).

${ }^{8}$ Schreiner $(1963,396-405)$.
} 
million plus interest - though with no reimbursement for the fact that the value of the contracts was around three times higher.' However, a break-out group owning 15 contracts, initially led by Christoffer Hannevig jr., refused to enter into an agreement with the US authorities. When their case was brought to arbitration in the Hague they received a smaller amount per contract than the less-aggressive owners. However, the interwar period was characterized by unpredictable fluctuations in most economic variables, and the recent depreciation of the Norwegian krone more or less neutralized the negative effect. ${ }^{10}$

For most shipping companies the Armistice of 11 November 1918 signalled the start of an optimistic period. Many companies had large funds available from a number of sources; insurance claims from vessels that had been lost, capital that they had raised from new investors eager to get a piece of the bullish market, and reserves built up as a result of the high profits during the war. In tune with this optimism, and encouraged by the possibility of avoiding excess tax, many companies had entered into newbuilding agreements. The ships were intended to go straight from the shipyards and into the prosperous post-war market, and the main problem was finding vacant building berths, not financing the investment. However, due to the high demand for yard capacity, there was a substantial delay in delivery; some shipowners had ordered vessels that could not be delivered until 1922. By then, the market had crashed.

Just like shipping had facilitated "the first era of globalization," the rebuilding of the world economy after the war would depend on shipping. Investors acted according to this belief, and in the slightly more than two years from the end of the war in November 1918 to December 1920, the world fleet increased by 39 per cent. ${ }^{11}$ The post-war market was indeed prosperous, but for less than 18 months. ${ }^{12}$ Shipping cycles peaked in February and March 1920. Then, abruptly, the market collapsed,

\footnotetext{
${ }^{9}$ Kloster $(1935,126)$.

${ }^{10}$ See Egeland (1973, 146-148); Egeland was present in the United States as representative for the Norwegian Shipowners' Association.

${ }^{11}$ Klovland $(2017,8)$.

${ }^{12}$ Furthermore, for parts of the prosperous period, regulations from the war, including maximum freights, were still in force.
} 
reaching a trough around a year later. ${ }^{13}$ The post-war adjustments were over more rapidly than anticipated, stocks were high and the international economy never really recovered. Shipping was hard hit, as employment for the ships became extremely difficult to find, even at very low rates.

During 1920 freight rates dropped by around three-quarters-one Norwegian shipowner compared the situation to "when the bottom falls off a barrel." "14 Ship prices followed suit, as lay-ups increased to a level that had not been seen before-and has never been seen since. The figure usually quoted is that half of the world fleet was idle at the worst point around the middle of 1921. The aforementioned Sagatind had made good money during the boom in 1920 , with the owners paying a 10 per cent dividend, but the ship was laid up from early December 1920 to the beginning of August 1921. ${ }^{15}$

Still, this unsurpassed overcapacity was a short-lived shock, and had limited long-term effects. Although the severity was extreme, the postwar crisis was brief and more normal conditions returned quite rapidly. Thus, due to the brevity of the crisis, the overcapacity and high lay-up rates did not have the kind of detrimental effect on shipping company revenues and equity that we see during the longer, but less-violent, crises in the 1930s and 1970s.

In 1920 Norwegian gross freight earnings-shipping income from abroad-amounted to almost NOK 1.3 billion, a record that would remain until the Second World War. Figure 4.1 shows the development of the gross freight earnings in the first four decades of the 20th century, and the data illustrate the dramatic boom-and-bust that the First World War and the brief post-war boom represented. ${ }^{16}$

\footnotetext{
${ }^{13}$ Klovland $(2016,19)$.

${ }^{14}$ See Castelein (2015) or Klovland (2016); quote from shipowner Thoresen in Christensen (1933, 14).

${ }^{15}$ When Sagatind started trading again, one of its first cargoes was forest products that were transported on behalf of the Soviet authorities. This voyage also created quite a stir in the Norwegian press, as the timber originated with a previously Norwegian-owned sawmill that the "Bolsheviks" had "nationalized"; Aftenposten, 270722, 3. The Drammen shipowners Friis \& Lund really knew how to pick the right customers.

${ }^{16}$ Figure 4.1: Gross freight earnings from Statistics Norway $(1948,277)$, with real figures deflated by means of the data in Grytten (2004).
} 


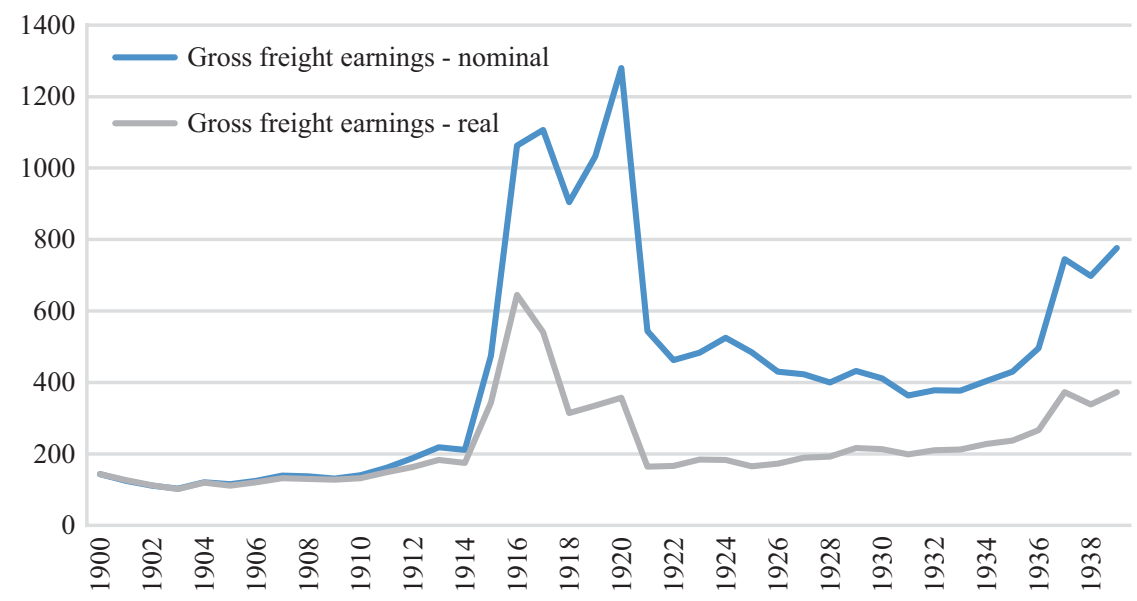

Fig. 4.1 Gross freight earnings, nominal and real, 1900-1939, NOK million. (Source: Statistics Norway $(1948,277)$. See footnote)

The period 1900-1939 was characterized by violent price movements, both strong inflation and periods of deflation, which obscure the actual development. In real terms, revenues from abroad during the prosperous years (1915-1920) were typically around three times higher than in the period 1900-1914, and twice as high as in the subsequent period of peace (1921-1938). Consequently, even with the collapse of the 1920s and the crisis of the 1930s, Norwegian shipping revenues followed a gently upwards-sloping trend, and the level during the interwar period was on average around 50 per cent higher than before the war.

This positive development was atypical in an international perspective. For world shipping in general, the interwar period was characterized by structural changes, overcapacity and low profits. Freight rates saw a steep decline in the first half of the 1920s, while the 1930s were another "dismal period for the shipping industry." ${ }^{7}$ The negative development of the shipping market reflected more fundamental problems in the world economy.

The attempts at rebuilding the international economy after the war were botched. Although the 1920s were prosperous and "swinging" in

\footnotetext{
${ }^{17}$ Klovland $(2016,17)$.
} 
the United States, the world economy never rediscovered its pre-war rhythm. One problem was monetary conditions. The Germans paid war reparations to France and the UK, that used the money to service their war debts to the United States. How could the war-torn Germans finance this? Well, they borrowed money from the Americans. In monetary terms, the interwar period was a merry-go-round let loose, with mercurial exchange rate fluctuations, hyperinflation and extreme instability in the world economy.

A second problem was the lack of a hegemonial power; a sunset Europe that was unable to take responsibility for the functioning of the international economy. Before the war, European imports had been financed by a combination of "invisible earnings" from shipping, return on investments abroad and export revenues. Following the war, the decline of the European fleet reduced shipping earnings. Liquidation of investments, partly to finance the war, partly due to the "disappearance" of large debtors such as Tsarist Russia, implied that Europe had gone from being net creditor to becoming net debtor. Finally, the reduced advantage in manufacturing production-neutral countries had built up their own capacity-aggravated the adverse balance within merchandise trade. The limited scope for manufacturing exports was made even more difficult as a result of increasingly protectionist policies in important markets.

For shipping, the most important problem was international trade, where the First World War and the interwar depression had a negative effect. The liberal world order, characterized by relatively free trade, did not recover after peace had returned. Tariffs, quotas and other restrictions introduced during the war were difficult to remove, and well-organized interest groups fought to maintain their privileges. Protectionism had spread to new countries and new industries. For the shipping industrywhose basis is international exchange of goods and commodities- the breakdown of the liberal trading regime was particularly problematic.

When international trade sneezes, shipping catches a cold. When international trade catches a cold, shipping gets pneumonia. The interwar period never saw the kind of strong trade growth that had been characteristic for the decades before the war, and with the onset of the Great Depression international trade collapsed. However, uncritical use of trade data gives an overly negative picture of the development of shipping 
demand. For instance, although the value of world trade decreased by around 60 per cent from 1930 to 1932, this was primarily driven by a strong reduction of prices. Ships move cargoes, not money. In actual terms, the volume reduction-and the effect on shipping-was much lower.

Despite all the rhetoric about the slow growth of trade and the interwar collapse of the international economy, shipping demand in 1937 was in fact around 75 per cent higher than it had been in 1913, despite the fact that data on the development of world trade volumes only present a growth of 25 per cent. Three factors explain the fact that the demand for seaborne transport grew faster than trade in general. First, trade in raw materials - relatively heavy commodities that take up a lot of shipping capacity-increased faster than trade in less shipping-intensive cargoes such as foodstuffs and finished goods. Second, an increase in average distances pushed up transport demand. Finally, due to the increased specialization and changes in the international trading pattern, ships spent a larger share of their time in ballast. ${ }^{18}$

\section{International Shipping in Transition}

The best example of the increased specialization is probably the interwar growth segment par excellence - oil tanker shipping. The main shift in seaborne energy transport was a relative reduction in the role of coal, and the concomitant upsurge of oil transports. Consequently, demand development was very conducive to oil tankers - and the tanker fleet increased tremendously. At the beginning of the 1920s, the tanker fleet made up less than 6 per cent of the world fleet and amounted to slightly more than 3 million gross registered tons. Almost 90 per cent of this was controlled by owners, mainly oil companies, in the United States and the UK. By 1937 the proportion of tankers had increased to more than 15 per cent, and American and British interests now controlled around half of this tonnage. The third largest fleet-slightly less than 20 per cent of all tanker tonnage-was owned by Norwegian shipping companies.

${ }^{18}$ Seland (1953, 11, 46-49). 
The growth in the demand for oil transport is only one half of the story about Norwegian tanker expansion. The other half of the story is something that most of us tend to think of as a modern phenomenon: outsourcing. Starting before the war, but accelerating in the second half of the 1920s, there was an important shift in ownership of oil tanker tonnage. A substantial portion of tanker transport was outsourced from oil companies to independent shipping companies. In 1900 independent shipping companies owned around 10 per cent of the tanker fleet, compared with 80 per cent owned by oil companies and 10 per cent by governments. By 1923 the independent fleet had increased to 25 per cent of the tanker fleet, and by 1939 to almost 40 per cent. ${ }^{19}$ This share increased amidst a tremendous fleet growth; the amount of independent tanker tonnage ballooned from 36,000 gross registered tons in 1900 to almost 4.3 million tons four decades later-an average annual growth of 13 per cent.

By leaving part of the transport to external service providers, the oil companies freed up resources to do what they did best-look for and exploit oil resources. However, a considerable share of the independent tanker tonnage was tied to the oil companies on charters of relatively long duration. The most famous outsourcing case concerned tankers sold from Anglo-Saxon Petroleum Co. - the transport arm of Royal Dutch/Shellwith 10 -year charters back to the sellers. An impressive 26 of the 28 ships that were outsourced in the period 1927-1930 ended up in Norway, many of them on the South Coast.

Through a combination of purchases of second-hand oil company tonnage and an ambitious newbuilding programme, Norwegian shipping companies built up the world's largest independent tanker fleet. The oil tankers - with their highly specialized technology—supplemented liners and tramp vessels, and also encouraged another technological shift: the replacement of steam engines by diesel engines. This transformation also had implications for work on board-coaling jobs were removed and "the soot angels" were left on the ash heap of history. The character of life at sea changed dramatically in the decades either side of the turn of the century. First, the old shanties from the sailing ships were no longer

\footnotetext{
${ }^{19}$ Data from British Petroleum, cited in Middlemiss (1996, 14).
} 
heard, as steam replaced sails and work in the masts was replaced by hauling of coal. Now that new type of labour-intensive activity has gradually disappeared as well.

The interwar period also saw a major shift in market shares in international shipping. There was a strong decline in the supremacy of the two major maritime powers - the United States and the UK. The United States had been oriented inwards - the way to the west was more enticing than the sea-through much of the second half of the 19th century. Indeed, the shipping and shipbuilding expansion during the First World War was a break from the norm. After the hostilities had ended, the United States established a large reserve fleet, to show readiness for another war situation. However, within commercial shipping, there was hardly any new investment. In the period from 1923 to 1939, the average age of the US fleet increased by 11 months annually. ${ }^{20}$ The United States was better off leaving shipping to foreigners.

The basis for the British decline was different. In the 19th century, Britain had large advantages in manufacturing production, and also oversaw a political and commercial empire that spanned the world. ${ }^{21}$ The history of the UK in the 20th century is the story of decline. Step by step the British advantages disappeared. The knowledge of how to build efficient machines, including steamships and their engines, was transferred to other countries. British coal was replaced as the main source of motive power. Finally, Britain's commercial and political empire was falling apart.

When the two leading maritime nations faltered, other countries were ready to take over. Four countries, in particular, managed to grab large market shares in the interwar period. Germany, starting from a low point with a practically non-existent merchant marine after the First World War, regained its former position as one of the world's leading maritime nations. In Japan, where the fear of colonization had gradually become replaced by imperial ambitions, the merchant marine played an important

\footnotetext{
${ }^{20}$ See Tenold $(2006,123)$.

${ }^{21}$ The song "Rule, Britannia!" was written in the 18th century, as a response to the infamous War of Jenkins' Ear. The shift from the imperative "Britannia, rule the waves" to the "vulgarly misquoted" statement "Britannia rules the waves" took place in the 19th century; Livingstone (2016, 186-187) and The Windsor Magazine, 1915, 73.
} 
political role. ${ }^{22}$ The growth of the German and Japanese fleets of course reflected the countries' role in the world economy.

The final challengers were less obvious; Norway had already been established among the Top Five of the world's maritime nations, but in the interwar period the Norwegian shipowners really solidified their position, increasing their share of the world fleet. While the world fleet practically "stood still," in tonnage terms, from 1923 to 1939, the Norwegian fleet more than doubled. ${ }^{23}$ The expansion was to a large extent based on oil tankers with diesel engines, so by the end of the interwar period, the Norwegian fleet was both bigger and better. However, an increasing focus on the liner trade and a consistently strong position in old specialties such as the Caribbean fruit trade also helped the Norwegian fleet's expansion. ${ }^{24}$

The strongest growth in relative terms took place in Greece. ${ }^{25}$ The country had been independent since the first half of the 19th century, but gained important territorial advances, primarily at the expense of the Ottoman Empire. Today, Norway is the only European country with a longer coastline than Greece, and the local basis for international shipping is not too different in the two countries.

The Greek expansion partly had the same foundations as the Norwegian, based on family and local connections. It had a decentralized pattern, with strong ownership interests on a number of islands. Many of the shipping companies did not have an administrative structure onshore, as "the technical and operational management of the ship took place at sea." ${ }^{26}$ The country did not see a movement of shipping to the leading

\footnotetext{
${ }^{22}$ See Chida and Davies (1990), for the best English-language introduction to Japanese shipping.

${ }^{23}$ Calculated on the basis of Lloyd's Register Statistical Tables, various years. Figures do not include the US reserve fleet; see Tenold (2006, 246).

${ }^{24}$ In the middle of the 1920s, Norwegians accounted for around 60 per cent of the ships that were employed in the US fruit trade. They also had a large share of the transport of fruit from Spain in the summer - ships that in the winter often carried forest products; Egeland (1930, 43-44).

${ }^{25}$ The Greek fleet increased on average by almost 6 per cent annually from 1923 to 1939 . For the basis of the expansion, see Harlaftis (1996, 181-206). For the other main nations, the Norwegian increase of 4.6 per cent came second, Germany with 2.5 per cent came third, and Japan's 1.62 per cent came fourth. The biggest decline was in the United States (minus 2.2 per cent), while the British fleet's increase during 1923-1930 was more than neutralized by its decline during 1930-1939, leading to an annual net decline of 0.8 per cent; see Tenold $(2006,117)$.

${ }^{26}$ Harlaftis $(1996,87)$ and Harlaftis and Theotokas $(2004,30-33)$.
} 
urban centres, like in Norway. Indeed, when such a shift occurred in Greek shipping after 1945, it was not only to Athens and Piraeus, but also to the metropolises of London and New York.

The increase in the merchant marines of Germany and Japan can be explained by their large and growing economies. The ships aided and abetted expansive imperial ambitions that would subsequently come to have disastrous effects. Norway and Greece, on the other hand, had limited imperial ambitions and were relatively unimportant in international trade. However, they shared certain characteristics; limited domestic resources, long coastlines and an even longer maritime heritage. A crucial point for both countries is that their rise to the top of the shipping market has been centred on foreign, rather than home, demand. ${ }^{27}$

This latter element was even more notable in the case of Panama, the first of an unlikely group of maritime nations that entered the shipping market in the interwar period and would go on to dominate it in the last part of the 20th century. Panama was a small, poor country, but with an important role in international shipping after the opening of the Panama Canal in 1914. Five years later, Belen Quezada, a former US navy ship, became the first foreign vessel to fly the Panamanian flag.

The expansion of the Panamanian fleet is a reflection of the footloose nature of shipping. Part of the basis for the use of the registry was US policy - a reaction to the introduction of the labour-friendly Seamen's Act in 1915, which increased the cost level substantially for American ships. Interestingly, the man responsible for the "emancipation of [American] seamen" was a Norwegian immigrant, "Andrew Furuseth, the head of the International Seamen's Union (ISU) and a man of such implacable determination and virtue that he was frequently compared to Lincoln and Jesus." 28

The Seamen's Act included minimum levels of crew size, as well as requirements for specific skills and payments. These regulations made ships registered in the United States particularly expensive and uncom-

\footnotetext{
${ }^{27}$ While Norwegian shipping companies had relied on intercontinental trade since the last part of the 19th century, Greek companies initially had more of a "home waters" bias. In 1938 almost half of the port entries of Greek ships were in the Mediterranean and the Black Sea, but after the Second World War Greek owners became more international and more "exiled" than anyone else.

${ }^{28}$ Gibson and Donovan $(2001,116)$.
} 
petitive in many markets, and could be alleviated by the transfer to the Panamanian flag. Another impetus came from the Prohibition. Belen Quezada was a smuggling ship, which was followed on the Panamanian register by two "dry" US cruise ships that feared losing their market if they were unable to ply passengers with alcohol.

The final consideration that made Panama attractive was tax. The desire to avoid "double taxation" of profits in the UK and the investors' home countries was important when the whale ship Vikingen was transferred to the Panamanian flag in 1931. Subsequently, Honduras became the second "Flag of Convenience," primarily promoted by the United Fruit Company's desire to transport bananas cheaply. ${ }^{29}$

Although the first Flags of Convenience were introduced in the first half of the 20th century, the scale was limited, and the majority of those that used the new opportunities had specific purposes-they were to some extent "Flags of Refuge." The Flags of Convenience did not create any major controversy until after the Second World War. However, it was already evident that the special character of the shipping industry-its operation in unclear jurisdictions - created a need for special, and internationally coordinated, solutions. In 1920, the second conference of the International Labour Organization (ILO), held in Genoa, dealt specifically with shipping. According to the contemporary edition of Encyclopedia Britannica; "Of all industries, the shipping industry is the most essentially international, and of all callings the seaman's has perhaps received the least attention from the legislator." 30 This omission was what the ILO wanted to rectify, and the global character of shipping meant that it was a good test case for how the new organization could influence working practices.

In the early 1920s, ILO introduced a number of conventions regulating issues such as the minimum age for seafarers (14 years), unemployment indemnity for shipwrecked sailors, compulsory medical examination of seafarers under the age of 18 , and so on. Another major issue was the suppression of the system of "crimps"-employment agencies that

\footnotetext{
${ }^{29}$ Carlisle (2009, 2017). Carlisle (2017), Chapter 7 also counts Danzig as the very first Flag of Convenience, but the juridical basis for this is so specialized that it is not usually taken into account.

${ }^{30}$ Entry "International Labour Organization”, Encyclopedia Britannica, 1922 edition.
} 
operated in a "dark, dark grey area," sometimes with shady tactics to ensure income from sailors looking for a ship to sign on. ${ }^{31}$ Still, although a framework was in place to protect seafarers, the manner in which this was followed up in practice was far from impressive, and often the legislation was simply ignored. In an interwar period with substantial unemployment, workers - even the unionized ones- had been dealt a bad hand.

\section{The Hare and the Tortoise: From Laggards to Leaders}

In Norway, regional seafarers' organizations dated back to the second half of the 19th century, primarily for captains. ${ }^{32}$ However, from the beginning of the 20th century, the various groups of ratings also formed their own organizations; Bergens Stuertforening organized chief stewards from 1902, while able seamen and stokers started organizing around 1910.

The new organizations and legislation did improve the seafarers' lot. However, the main impetus for a safer and healthier life at sea did not come from unions or authorities. Rather, it was a result of technological improvements and the modernization of the Norwegian fleet. Although the conditions were far from luxurious, both the quality of board and lodging and the overall safety improved appreciably. Food regulationspartly as a response to scurvy, beriberi and other diseases—became based on nutritional science, and were helped by improved storage and shorter voyages. ${ }^{33}$ Refrigeration improved food storage, and electricity improved

\footnotetext{
${ }^{31}$ See Bruijn (2005, 15-16), Bolle (2006) and Fink (2016), for an introduction to the maritime work of the ILO.

${ }^{32}$ Captains had been organized in guilds, with specific rights and obligations, centuries before this, but the first Captains' Associations [Skipperforeninger] were established in the middle of the 19th century.

${ }^{33}$ There were no requirements with regard to the quantity or quality of onboard food before the late 19th century. See Kloster (1942, 64-87) for an overview of the regulation of onboard provisions, with an emphasis on food. Based on contemporary sources, Kloster characterizes the victualling before 1840 as "meagre," although with ample servings of spirits, to "wake up" the crew in the morning when the ship was in port, and several times daily if work was particularly hard. From 1840 to 1870 spirits had usually been replaced by coffee, but the food was "much better, but still
} 
sanitation. Still, the main technological advance was not related to welfare: "Comfort may be overestimated, but the technology that creates safety, cleanliness and convenience for passengers, at least deserves respect." 34

Better food and cleaner surroundings helped seafarers in the long term; improvements in communications reduced the short-term dangers. The interwar period is known as the Golden Age of Radio, where the new technology had a massive cultural influence, in particular in the United States. At sea, the cultural impact was limited, but the overall effects even more important. In 1931 the first international radio code was published; still organized in a manner similar to the old flag signals, though vastly more useful over longer distances and when visibility was limited.

The frequently used Lombard code book contains more than 1200 pages of five-letter codes, and the amount of detail is staggering. It contains, for instance, around 22,500 codes denoting ports and places, more than 17,000 codes covering particular ships and at least 14,000 company addresses. The largest portion of the book-general codes-covers in excess of 830 pages. Among the more than 187,000 codes can be found, for instance, CLRKK (absinthe), GMRDA (drunkenness) and FPBDU (accidental death). ${ }^{35}$ Another recent invention was radio navigation; "undoubtedly the best aid for safe navigation both on the ocean and along the coast." 36

The improved communication became particularly important when it was combined with progress in other areas. Advances in the science of meteorology — to a large extent originating in Bergen-made the improved access to information particularly useful. Similarly, a service providing medicinal advice was established, implying that even small ships could benefit from access to qualified doctors. By the late 1930s, more than 400 Norwegian ships had shortwave radios installed, and were

simple." To illustrate the basic character of the equipment: in the middle of the 19th century, Norwegian sailors on US vessels were impressed by the fact that there was a medicine chest onboard.

${ }^{34}$ Kent $(1925,4)$.

${ }^{35}$ See Lombard (1934).

${ }^{36}$ Mohn (1942, 104). 
able to stay in direct and frequent contact with the home country from practically anywhere in the world. ${ }^{37}$

Many shipowners began to take the welfare of sailors more seriously, and new vessels — in addition to some old ones-were equipped with book collections, both prose and educational literature. Indeed, seafarers were encouraged to use their spare time to study, in order to rise in the ranks. Norwegian owners and officers were also praised for their "admirable interest in and consideration for the crew's well-being and satisfaction." ${ }^{38}$ In particular, the quality of the cabins and mess rooms was praised; the mess rooms for engine personnel on Norwegian tankers, were claimed to be of the same quality as the officers' mess rooms on British ships.

The most important improvement, however, was probably in the quality of the ship's structure-its seaworthiness, manoeuvrability and materials. In the 1890s, more than four Norwegian vessels were lost at sea every week. In the 1920s the corresponding figure was just above one, while in the 1930s "only" 37 ships were lost in an average year. ${ }^{39}$ One reason for the decline was that the old, leaking and accident-prone sailing vessels died out and were replaced by state-of-the-art modern vessels. The average age of the Norwegian tonnage fell from around 19 years in 1914 to less than 13 years in $1939 .{ }^{40}$

From the early 1920s to the outbreak of the Second World War, the average age of the Norwegian fleet remained more or less the same, around 12-13 years. This had two implications. First, although the average age was the same, the fleet each year became one year "more modern"; it is the year the ship is built, not the age, which determines the level of its qualities. Second, although the Norwegian average age was static, the international fleet aged substantially in this period, as a result of lacking investment. In 1923 the average age was more or less the same as in

\footnotetext{
${ }^{37}$ Not everyone was happy about the development; a Bergen captain allegedly said that "We are indeed flooded with telegrams when we are in port; why should we be bothered by them at sea as well"; Albretsen (1942, 119).

${ }^{38}$ An anonymous British newspaper article quoted in Egeland (1930, 32).

${ }^{39}$ Calculated on the basis of Statistisk Sentralbyrå $(1968,177)$.

${ }^{40}$ The figure for 1913 is estimated on the basis of data in Einarsen $(1938,110)$. Apparently, the average age around 1880 was more or less the same; rough calculations based on Tønnessen (1951, 141).
} 
Norway, by 1939 it had increased to almost 17 years. Consequently, compared with other countries, the Norwegian fleet became more modern, more competitive and more attractive.

The technology historian Håkon With Andersen has referred to the dramatic interwar transformation of the Norwegian fleet as a development from laggards to leaders. ${ }^{41}$ As previously mentioned, Norway was no pioneer in the transformation from sail to steam. On the South Coast, in particular, sailing ships dominated well into the new century, and in 1916 Kristiansand was the sailing ship capital of the world, with almost 70 iron and steel sailing vessels. ${ }^{42}$

The pre-war tonnage level for steamships was regained in 1921, and the steamship fleet continued to increase until peaking in 1931. From then on, the reduction in steamship tonnage was offset by an increase in motor-driven vessels. By the beginning of 1939, Norway's share of the world fleet was around 7 per cent-more than double what it had been when the war ended, and for tankers the market share was an impressive 18 per cent.

The sailing ship fleet, on the other hand, silently disappeared during and shortly after the war. Counting around 1000 ships, and more than 600,000 gross tons, when the war broke out, only around a quarter of the ships were left by 1925 . These were primarily the smaller, local vesselsin tonnage terms, the reduction from 1914 to 1925 amounted more than 90 per cent. ${ }^{43}$ Around 180 ships, totalling almost 190,000 tons, were lost during the war. ${ }^{44}$ In percentage terms the direct war losses amounted to slightly more than 30 per cent, compared with more than 50 per cent for the steam and motor ships. However, lack of reinvestment and natural scrapping of obsolete tonnage meant that the sailing ship fleet declined by more than half from 1914 to 1918, compared with a net reduction of roughly a quarter for the steamships. Nevertheless, as late as in 1920 there were still almost 80 sailing vessels larger than 1500 tons in the Norwegian fleet.

\footnotetext{
${ }^{41}$ Andersen (1992).

${ }^{42}$ Seland (1959, 258).

${ }^{43}$ Estimated on the basis of Statistics Norway (1948, 242).

${ }^{44}$ Vigeland (1949, 256).
} 
The sailing ships had remained competitive in certain trades-in particular the transport of potassium nitrate from Chile-and on long distances. However, they were clearly a dying breed - and a large proportion of them died from "natural causes." One example is Skaregrøm, one of Norway's last commercially operated square-riggers, built in Port Glasgow on the Clyde in 1903. When the vessel was bought second-hand by the Grimstad-based shipowner Johan Bang in 1924, it was renamed after an old wooden barque that the owner's grandfather had built at his own yard in Grimstad in 1877. The first Norwegian-built Skaregrøm was lost on a trip from Marseille to New York in 1891. The name Skaregrøm is thus a good example of both the changing strategies (and the unchanging fates) of ships and shipowners on the South Coast.

In November 1926 the Scottish-built Skaregrøm finished loading timber in Fredrikshald (Halden), on the east side of the Oslofjord, and set sail for Australia. The captain, Peder Johannessen, had brought his wife and two of their children on the voyage. A week before Christmas, a major storm destroyed the rigging, leaving only the foremast and "a stump of the mizzen-mast." Johannessen managed to take the ship to the Azores, where Skaregrøm was condemned. The ship was subsequently towed to London, where the valuable cargo was sold. Captain Johannessen received a gold medal, and also a gold watch from the cargo's insurer. ${ }^{45}$

The sailing ship era was undoubtedly over in the interwar period, and in its final years the decline went rapidly. The shipping company S.O. Stray in Kristiansand, which owned 20 sailing ships in 1920, had disposed of all by $1925 .{ }^{46}$ The city's sailing ship fleet declined from almost 50 ships in 1920 to 34 in 1922 and only four in 1925. Many of the Norwegian sailing ships were scrapped, others were lost and some were sold to foreign shipowners, for instance Åland's Gustaf Erikson, who operated windjammers in the South Australian grain trade. ${ }^{47}$ Some had

\footnotetext{
${ }^{45}$ Based on Bakka (1998, 14-15), Vigeland (1949, 257-258), Drevdal (1994, 137-140).

${ }^{46}$ With wonderful irony, the main reason that S.O. Stray was liquidated some years after the last sailing ship was sold, was its badly timed investment in three modern motor ships, not the fact that the majority of the company's fleet had been sailing ships in the era of steam and diesel; Seland (1959, 226-229).

${ }^{47}$ See Newby (1956). Although the Skaregrom had an unfortunate fate, Pommern, a former Eriksson-ship and a close, slightly larger cousin—also built in Port Glasgow in 1903—has survived and is today a museum ship in Mariehamn, Åland. See also Kåhre $(1977,1980)$.
} 


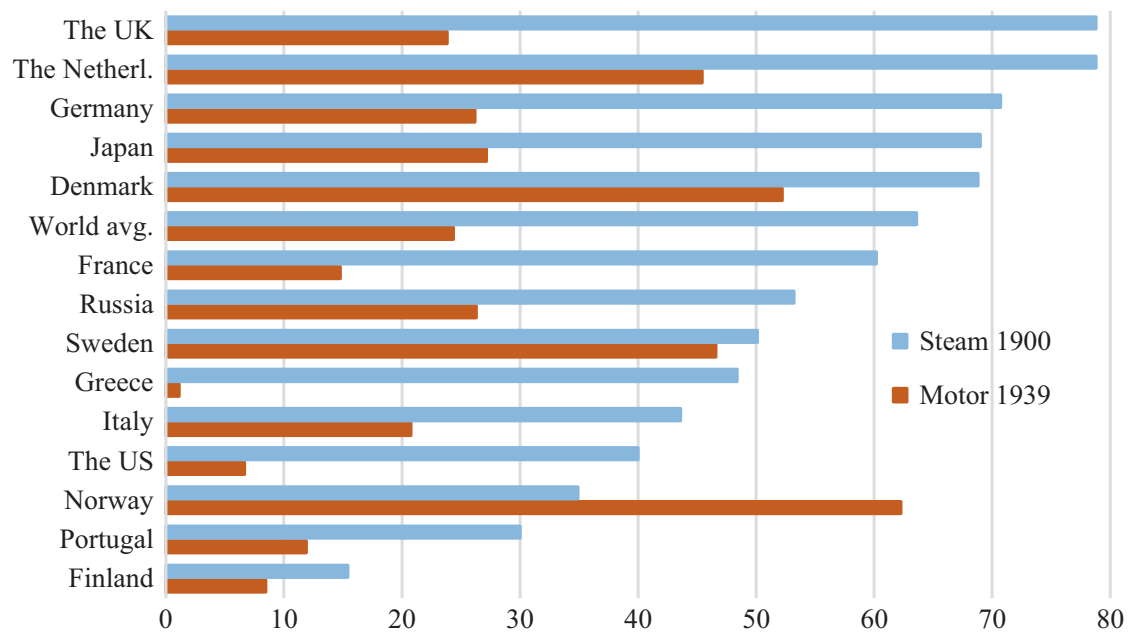

Fig. 4.2 Steam and motorship shares, per cent, 1900 and 1938, based on gross tonnage. (Source: Statistics Norway $(1902,168 ; 1939,324)$. See footnote)

more unconventional fates. The Stray-vessel Alastor, after a stint in Finnish ownership, ended up as the restaurant ship Bounty in the harbour of Margate in Kent after the Second World War. ${ }^{48}$

Figure 4.2 clearly illustrates the transformation of the Norwegian fleet from a technological laggard at the start of the century to a technological leader at the end of the interwar period. ${ }^{49}$ Only relatively poor and technologically backward countries such as Portugal and Finland had a higher share of sailing ship tonnage than Norway at the start of the century. While steamships made up almost 64 per cent of the world fleet, in Norway the share was less than 35 per cent. Less than four decades later, more than 60 per cent of the Norwegian fleet consisted of the most

\footnotetext{
${ }^{48}$ Motorboating, December 1949, 31.

${ }^{49}$ Shares in 1900 refer to the end of the year fleets of vessels larger than 50 tons and are calculated on the basis of Statistics Norway $(1902,168)$, with no adjustment between steam and sail tons. Figures for Russia refer to 1899 , and include vessels smaller than 50 tons but not ships in the Caspian Sea and the Pacific ports. Italian figures are estimates. Shares in 1939 refer to the June fleets of steam and motor ships larger than 100 gross tons and sailing ships larger than 100 net tons and are calculated on the basis of Statistics Norway $(1939,324)$. The share for Great Britain and Ireland is calculated on the basis of data that include the Dominions and colonies, but this is unlikely to change the overall picture much, due to the large share of British tonnage (around 85 per cent).
} 
modern technology—-the motorship_compared with less than a quarter for the world fleet.

The underdog is loved by history-or, more precisely, by historians. And the underdog-in the shape of the once-proud sailing shipowners on the South Coast of Norway-has traditionally played an important part in the narrative of Norwegian tanker shipping in the interwar period. These shipowners - left by the wayside (or the seaside?) during the transformation from sail to steam-saw a Phoenix-like return in the interwar period, emerging successfully in the transition to the "new" technology, the oil tankers. The Anglo-Saxon vessels were their tickets in the tanker lottery. As the seller provided financing, the purchase of these vessels was a good deal for cash-strapped companies, and 16 of the 28 ships were eventually sold to companies based on the South Coast.

Closer analysis has revealed that the Anglo-Saxon purchases were but a small part of the Norwegian tanker tale. ${ }^{50}$ The main growth occurred among newly established companies, particularly in Oslo, that had close relationships to yards in Denmark and Sweden. ${ }^{51}$ The expansion was thus a pan-Scandinavian effort. Ships were built at yards in Sweden (around 35 per cent of the newbuilt tanker tonnage) and Denmark (around 15 per cent), but operated by Norwegian shipping companies, sometimes on long charters to the oil companies, at other times not. ${ }^{52}$

One of the main drivers behind the tanker investments was Hugo Hammar, managing director at Götaverken in Gothenburg, who walked around Oslo like a missionary, selling tanker tonnage as the economically attractive escape route from the depressed shipping markets. Helped by eager Oslo brokers, a substantial pressure was built up from the supply side, where both ships and mortgages were on offer. ${ }^{53}$ The authorities in several European countries, eager to ensure employment in their shipyards, contributed by offering generous financing that limited the

\footnotetext{
${ }^{50}$ Tenold (2007).

${ }^{51}$ The Norwegian capital was characterized by a sense of identity crisis around the turn of the century. In the official Norwegian nomenclature, Christiania became Kristiania in 1877, while the city authorities accepted the name change in 1897 . The name was formally changed to Oslo in 1925.

${ }^{52}$ Market shares based on the more than 200 diesel tankers built during 1925-1939 and listed in Det Norske Veritas, 1939.

${ }^{53}$ See Gunnerud (1992) for a comprehensive analysis.
} 
need for Norwegian equity and enabled the entry — or re-entry_ of companies with meagre resources. The credits offered by Hammar and Götaverken were initially 50 per cent over five years, but in the 1920 s they were increased to 70 per cent, at the same time as the repayment period was increased. ${ }^{54}$

The equity needed to buy a newbuilt Swedish tanker in the late 1920s was around NOK 650,000-a petty sum when we consider that quite ordinary ships could cost 3-4 million or more during the First World War. Typically, the money was raised from a large number of sources: families, friends, business associates and-in many cases very importantly-brokers eager to get commissions. A very telling example of a small and dynamic entrepreneurial venture is Moltzau's Tankrederi, which began its operations in the corner of the shipping company Ivar An. Christensen's waiting room. Ragnar Moltzau was Christensen's secretary. ${ }^{55}$ His first tanker contract, a ship in the UK ordered for delivery in the autumn of 1930, had to be resold as he was unable to secure financing following the stock market collapse. In the summer of 1930 Moltzau managed to raise NOK 750,000 in share capital. One-seventh of this came from two broker companies - one in Norway and one in the UKin exchange for exclusive brokering rights for the ship. ${ }^{56}$

Figure 4.3 shows the strong increase in the number of Norwegian tanker-owning companies, from 11 in 1919 to 107 in $1939 .{ }^{57}$ Regionwise, the East shot forward, led by Oslo, the South recovered and the West struggled to keep up. It is also very clear that the main basis for the tanker expansion was Oslo; while the number of tanker owners in Bergen doubled, the number in Oslo multiplied by a factor of 48 . The late, but significant, addition of the South Coast is also clear; Arendal-which got its first tanker-owning company in 1928-had as many companies as Bergen 10 years later.

\footnotetext{
${ }^{54}$ Bohlin $(1989,81)$.

${ }^{55}$ See Fasting (1955).

${ }^{56}$ Kolltveit $(1977,49)$.

${ }^{57}$ Figure 4.3: Based on information from various issues of the Veritas-registry. The dominant cities in the "Other" category are Tønsberg, with eight companies, Stavanger with six and Sandeford with five companies in 1939. South Coast includes Arendal (eight companies), Farsund (three), Flekkefjord (one), Grimstad (two), Kristiansand (five), Risør (two) and Tvedestrand (one).
} 


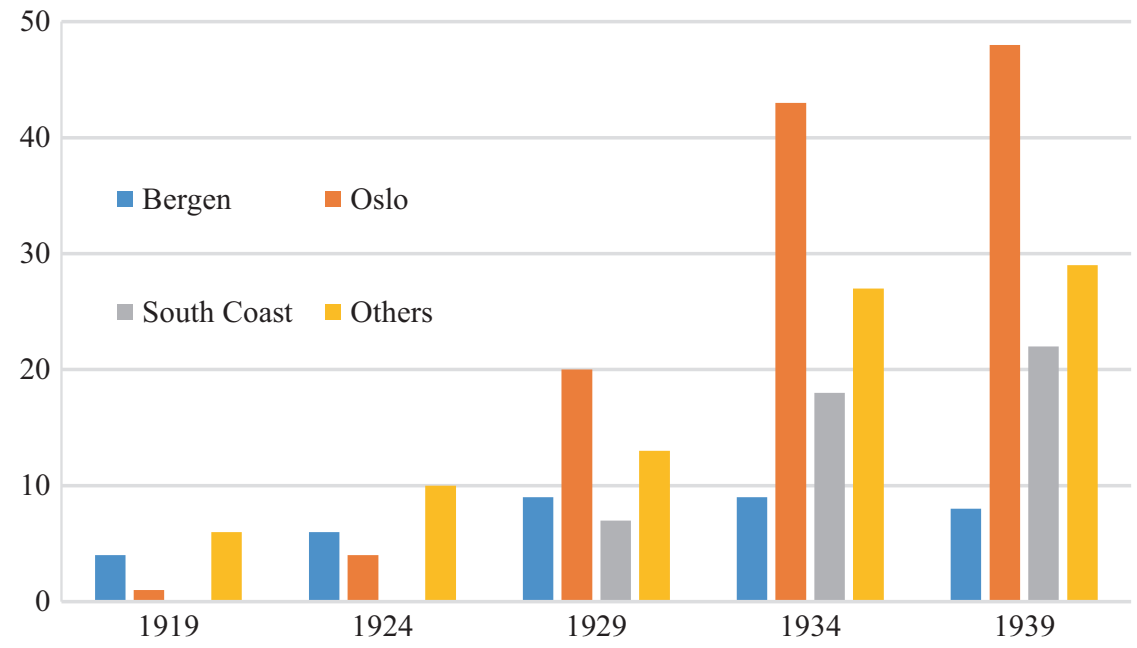

Fig. 4.3 The number of tanker companies in various Norwegian regions, 1919-1939. (Source: Veritas, various issues)

Parallel with the transformation of the Norwegian fleet, the manner in which shipping was conducted in Norway was modernized. With the demise of the sailing ship era, the traditional part ownerships had increasingly been replaced by limited liability companies. However, as many of the first limited liability companies were single-ship companies, the existence of the business was still closely tied to the existence of the vessel.

The interwar period saw a transformation from single-ship companies to multi-ship companies, which implied that the scope for continuity was greatly increased. Capital was raised in the same manner as before-with a relatively wide dispersion of ownership. However, the possibilities of arranging financing through the shipyard, and the improved access to outside capital from ship mortgage institutions, reduced the demand for equity.

The multi-ship companies allowed continuity, but also had advantages with regard to insurance, ship operation, access to credit and preservation of company-specific knowledge. This latter element had been taken care of through managing owners that oversaw the business of several companies, though the First World War showed how easily a hostile 
takeover could take ships out of the hands of the managers. Another advantage was the multi-ship companies' ability to "smooth out" the effects of business cycles on tax payments, dividends and employmentby definition the fate of the single-ship companies had been tied directly to their one vessel.

The transformation from traditional single-ship to multi-ship companies has been put forward as one explanation of the geographical shifts in Norwegian shipping in the interwar period. From 1920 to 1939 the fleet registered in Oslo increased substantially faster than that of Bergen, and that of Norway in general. ${ }^{58}$ Contemporary sources suggest that the reliance on an antiquated ownership structure explains why Bergen "was unable to keep up with the development of technology and business practice." 59

In his classic book on the decline of Great Britain's maritime hegemony, British Shipping and World Competition, Stanley G. Sturmey draws a parallel between the lethargy of British shipowners and the shipowners in Bergen. In both cases, a conservative attitude is used to explain why others took over the advantage. ${ }^{60}$ In the case of Oslo, the offensive attitude of the city's own shipping companies also got external help. The capital's growth in the first half of the 20th century was strengthened by the relocation of shipowners from other parts of the country; A.F. Klaveness from Sandefjord in 1907, Wilh. Wilhelmsen from Tønsberg — at the time the country's largest shipping company—in 1916 and Sig. Bergesen d.y. from Stavanger (1939).

The increasing reliance on motor vessels was not only a tanker phenomenon, but also related to another structural change in the operation of the fleet - the gradual reduction of tramp trade at the expense of ships operating on fixed schedules in dedicated lines. Liner companies were the royalty of international shipping, vehicles for transport and national prestige in the case of the UK, France and Germany.

\footnotetext{
${ }^{58}$ This is the main point in Thowsen (1983), which-though focusing on Bergen shippingthrough its comparative perspective is perhaps the best source of information on Norwegian shipping in the interwar period.

${ }^{59}$ Magnus $(1942,101)$.

${ }^{60}$ Sturmey (1962). Gjermoe (1964, 9-15) suggests that Bergen's problem was the number of older, smaller companies, with limited capital, that were based in the city.
} 
As opposed to the tramp trade, the liner trade was not characterized by free competition and flexible prices. The major liner companies cooperated in "conferences," cartel-like structures that fixed prices and sailing schedules and restricted capacity. The Norwegian companies had neither the financial muscle nor the networks needed to acquire a major position in the Atlantic trade. However, they managed to build up substantial niches in various parts of the world, sometimes on their own initiative and sometimes by initially providing a service for foreign interests, for instance by time-chartering vessels to foreign lines.

The first lines began as a vehicle for Norwegian exports— not the "third country"-shipping that had become characteristic of Norwegian companies. Thoresen's Den subvenerede Norsk-Spanske Linie [the Subsidized Norwegian-Spanish Line] relied on a government subvention of 75,000 kroner and the transport of timber and fish to Spain and Italy when it was established in 1894, and G.M. Bryde's line to Mexico-the first overseas line, established in 1908-also received some government support. The consortium behind the Den Norske Afrika og Australia Linie [the Norwegian Africa and Australia Line], established 1911, entered into "peace agreements" — non-competitive clauses - with lines on the Continent. They were granted a hegemony position in Scandinavia, if they refrained from picking up cargoes to and from Continental Europe.

When plans for a joint Scandinavian line were shelved, Den Norske Amerikalinje [the Norwegian America Line] became an almost nationalist and patriotic project. The first vessel, Kristianiafjord, was launched in the summer of 1913, with King Haakon VII, the cabinet and a large number of Members of Parliament among the dignitaries that joined on the first leg from Kristiania to Bergen. ${ }^{61}$ The line was not big enough to challenge the major conference participants, but small enough to be left alone by the otherwise predatory established lines. Still, before the war, the scale and scope of Norwegian liner shipping was limited.

In the interwar period the activity in the liner sector increased, and in his book on the Norwegian liner trade, Dag Bakka jr. refers to the interwar period as "The great expansion." By 1939 Norwegian shipping companies operated around 30 different lines. However, the number of

${ }^{61}$ Sebak $(2011,101-124)$. 
shipping companies involved in this business was not much larger than this, as several of the major companies participated in more than one line-Wilh. Wilhelmsen participated in seven and Fred. Olsen and J.L. Mowinckels Rederi both participated in four different lines. ${ }^{62}$

\section{Whaling}

Shipping was not the only industry that sent Norwegians to distant waters. In the second half of the 19th century a whaling community developed in the Vestfold-cities Sandefjord and Tønsberg, on the western side of the Oslofjord. Expeditions of 20-40 ships travelled to the coast outside Finnmark, in the north of Norway, to catch rorquals, finwhales and blue whales. A central premise for this development was the bombtipped "grenade harpoon," developed by Svend Foyn and mounted on small steam vessels - the whale catcher boats. Foyn, who came from a shipowner family, had trained as a captain and moved on from the transport of wood cargoes to sealing and whaling.

The new technology developed by Svend Foyn, "the father of modern whaling," was deadly efficient-a fact that was good for business in the short term, but harmful in a longer perspective. In 1904 a 10-year moratorium was introduced in Norwegian waters due to overexploitation of the resource- the grenade harpoon had increased the takings and threatened the local stocks. Around this time Norwegian whalers started a massive global expansion, venturing into both the Northern and Southern hemispheres and ending up with a leadership position in the Antarctic. There, land-based whaling stations at South Georgia—referred to as "the Island" by whalers-were complemented by floating whale factories around South Shetland. ${ }^{63}$

In the 1920s, the development of whale factory ships took the industry into the high seas, independent of shore facilities-what is usually referred to as "pelagic whaling." This activity was closely related to shipping along several dimensions. The two industries competed for investors

\footnotetext{
${ }^{62}$ Bakka (2008, 19-42).

${ }^{63}$ See Basberg 2006 for an interesting discussion of the economic history of the Antarctic.
} 
and labour, and several individuals - workers, investors and entrepreneurs-were engaged in both sectors. There was also an element of complementarity; the main product from the whaling was oil, and the whale factories could also be used to transport mineral oils.

In the 1920s revenues from whaling were substantial and provided important export revenues in a generally difficult period. However, with the improved technology, prices fell and the monopsony power of the main purchasers created problems. In the 1930-1931 season a total of 41 whaling expeditions, with more than 220 boats, produced more than 3.6 million barrels of oil. ${ }^{64}$ The Norwegian market share was more than 60 per cent; Norwegians operated five shore stations and 29 floating factories, supported by a total of 160 catcher boats. The Norwegians caught more than 25,000 whales, producing almost 2.3 million barrels of oil, with a value of almost NOK 150 million.

As share of Norwegian production, whaling reached a peak with slightly less than 5 per cent of GDP in the 1930-1931 season. In the subsequent season the market for fats was saturated, and most of the Antarctic whaling fleet was laid up. Production fell from more than 2.3 million barrels to 29,000 barrels. ${ }^{65}$ When activities were resumed, the Norwegians lost market shares to other nations. In 1927-1928 Norwegians had produced more than 70 per cent of the Antarctic whale oil, while 10 years later their share of production had fallen to less than 35 per cent.

In terms of economic importance, whaling was never a challenger for the shipping sector. Employment was relatively limited-less than 6500 persons at the peak in the 1930-1931 season-and the industry had an enclave-like position, with only limited spillovers, primarily to shipyards and mechanical industry. However, the spectacular profits from the industry during the peak-some years return on invested capital was 50 per cent or more-helped lay the foundation for investments in shipping. Several of the leading Norwegian shipping companies in the 20th century, particularly in Vestfold, made a mint in whaling and channelled the profits into traditional shipping. Among those that seamlessly

\footnotetext{
${ }^{64}$ Tønnessen and Johnsen $(1982,385)$.

${ }^{65}$ Statistisk Sentralbyrå (1968, 184).
} 
navigated the waters between whaling and shipping was Anders Jahresometimes referred to as "the Prince of Whales." Anders Jahre represented a new type of Norwegian shipowner, with academic merits rather than a seagoing past. Such a background was common for many of the newcomers in interwar shipping.

\section{The New Breed}

The interwar period saw a marked shift in entrepreneurial activity. Though there were still some captains that went ashore and established their own shipping companies, an increasing share of the new ventures were founded by a different breed of entrepreneur-by men with university degrees. Education in economics and law replaced practical seamanship as the basis for a number of newly established shipping companies. This included many of the shipowners who would dominate Norwegian shipping over the subsequent decades.

The previously mentioned Anders Jahre had a degree in law; in 1922 he started to invest in shipping, and in 1928 many of his shipping interests were gathered under the Kosmos umbrella. Leif Höegh, the most expansive of the interwar newcomers, was an economist. Hilmar Reksten, whose growth after the Second World War became almost as legendary as his subsequent downfall, was educated at the Handelshochshule in Cologne. Erling Dekke Næss, who established a shipping empire abroad and played a key role in the early growth of the Flags of Convenience, followed his economics degree from the University of Oslo with work in London, where he was heavily influenced by, among others, John Maynard Keynes. ${ }^{66}$

Although the new breed became important, few could challenge "the old guard," when new generations were ready to take over. In many of the

\footnotetext{
${ }^{66}$ See Næss $(1977,1981)$ for two fascinating autobiographical accounts of Erling Dekke Næss' colourful life in shipping, though with the flaws common for autobiographies. Næss claims that he started his business career speculating in goat cheese during the First World War. He had good mercantile genes; his father was a merchant-cum-banker who died young, while his grandfather was Annanias Dekke, perhaps the most innovative Norwegian shipbuilder of the 19th century; see Chapter 2.
} 
Table 4.1 The 10 leading Norwegian shipping companies, 1 September 1939, fleet size and structure

\begin{tabular}{|c|c|c|c|c|c|c|c|}
\hline Name & City & Est. & Ships & Grt. & $\begin{array}{l}\% \\
\text { motor }\end{array}$ & $\begin{array}{l}\% \\
\text { tankers }\end{array}$ & $\begin{array}{l}\% \\
\text { liners }\end{array}$ \\
\hline Wilh. Wilhelmsen & Oslo & 1861 & 53 & 324.000 & 89 & 2 & 98 \\
\hline Westfal-Larsen & Bergen & 1905 & 34 & 208.000 & 75 & 50 & 39 \\
\hline Knut Knutsen OAS & Haugesund & 1897 & 25 & 140.000 & 91 & 50 & 50 \\
\hline A.F. Klaveness & Oslo & 1869 & 22 & 118.000 & 96 & 45 & 47 \\
\hline Fred. Olsen & Oslo & 1886 & 53 & 113.000 & 66 & 3 & 71 \\
\hline Leif Höegh & Oslo & 1927 & 13 & 102.000 & 100 & 75 & 25 \\
\hline $\begin{array}{l}\text { Den Norske } \\
\text { Amerikalinje }\end{array}$ & Oslo & 1910 & 17 & 101.000 & 30 & 0 & 95 \\
\hline $\begin{array}{l}\text { Det Bergenske } \\
\text { Dampskipselskap }\end{array}$ & Bergen & 1851 & 51 & 92.000 & 36 & 0 & 47 \\
\hline $\begin{array}{l}\text { J.L. Mowinckels } \\
\text { Rederi }\end{array}$ & Bergen & 1898 & 16 & 86.000 & 77 & 41 & 35 \\
\hline Fearnley \& Eger & Oslo & 1869 & 19 & 75.000 & 84 & 23 & 51 \\
\hline
\end{tabular}

older family-owned companies, the idea of the Wanderjahre at sea for the successors, common before the war, was increasingly replaced by a period working onshore. The shipowners' sons would spend time abroad, gaining experience with other shipping companies or brokers. Another way in which the shipping sector acquired new talent was via marriage-some shipping companies explicitly barred daughters from taking over, but sons-in-law were often welcomed into the family business. ${ }^{67}$

Table 4.1 shows that the majority of the largest companies at the end of the interwar period had their roots in the 19th century, and only one had been established after the First World War. ${ }^{68}$

With the exception of the Bergen companies Westfal-Larsen and Mowinckels, and the tanker-focused newcomer Leif Höegh, the majority of the large shipping companies had 40 per cent or more of their tonnage in the liner segment. The larger Norwegian companies had the financial muscle to secure berths in the minor and remote conferences, sometimes using the provision of tonnage to existing participants as a stepping stone. They also expanded in the US market, where liner conferences were less

\footnotetext{
${ }^{67}$ See for instance the fascinating example of the identical twins that married into two prominent Haugesund shipping families in Hammerborg (2011).

${ }^{68}$ The table is based on the list in Thowsen $(1992,28)$.
} 
concerned about capacity. Revenues from the tanker sector were in many cases important to finance the new liner ships. Only Fred. Olsen and the two "home-based" lines_-Den Norske Amerikalinje and Det Bergenske Dampskipsselskap—expanded without any substantial revenues from tanker shipping.

\section{Not All Rosy}

Although the interwar period can be considered a successful period for Norwegian shipping per se, this was an era of rapid transformation, and abrupt changes typically leave victims in their wake. We find these victims both among the companies that did not manage to cope with the changes, and among the seafarers that were unable to find work.

Lay-ups reached their highest proportion of the fleet ever after the freight market collapsed in 1920, but the overcapacity was relatively short-lived. Figure 4.4 shows that the overcapacity in the 1930 s was more persistent. Lay-up rates amounted to more than 600,000 dead weight tons from 1931 to $1934 .{ }^{69}$

The ups and downs of the business cycle, and the effect of the lay-up rates above, were partly reflected in unemployment among seafarers. There were substantial differences in the unemployment rates among various branches of industry, and seafarers, as well as workers in cyclical industries such as construction, had particularly high rates. On average, unemployment rates among seafarers were slightly more than 11 per cent during the crisis in the first half of the 1920s, but more than doubled, to 23 per cent, in the first half of the $1930 \mathrm{~s}^{70}$ As a result of the lack of a social safety net, these abstract percentages hide some very real personal tragedies. Seafarers that were out of work in Norway could often rely on help from family and friends - the situation was more problematic for those who were far away from home.

\footnotetext{
${ }^{69}$ Figure 4.4: Calculated on the basis of data in Statistics Norway $(1929,84)$ and Statistics Norway $(1948,276)$. Biannual data have been interpolated for the period 1920-1926.

${ }^{70}$ Calculated on the basis of data for 1921-1925 and 1930-1934 in Grytten (1994, 177-178). Average unemployment for the total labour force was 4.8 and 9.2 per cent, respectively.
} 


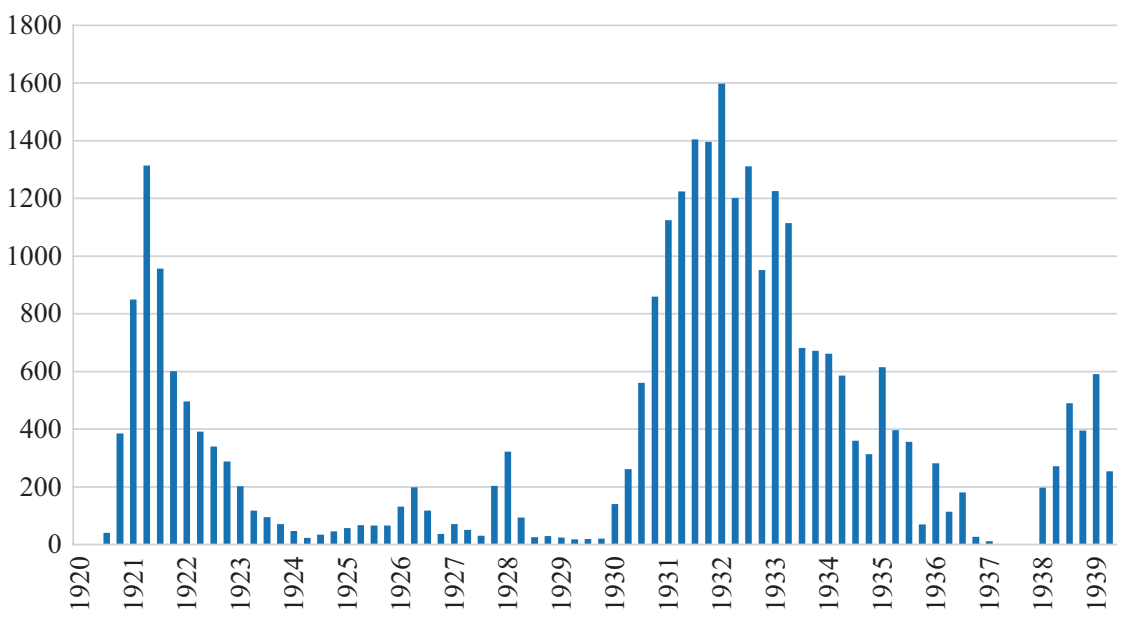

Fig. 4.4 Norwegian lay-ups, quarterly estimates, 1920-1939, 1000 dead weight tons (dwt). (Source: Calculated on the basis of various statistics from Statistics Norway. See footnote for details)

Some of the most tragic fates could be found in the borough of Brooklyn, in New York. Orkenen Sur [the Desert of Shur, a reference to Exodus] was a Hooverville where a large number of Norwegian sailors and ex-sailors found temporary shelter in the difficult interwar years. ${ }^{71}$ The Norwegian legislation did not provide them with money to get back to Norway and, in the crisis years, jobs in the declining American merchant marine were reserved for the country's own seafarers. A sailor who stayed more than 60 days in the United States without specific permission became an illegal immigrant, and had to watch out for the authorities.

Many of the inhabitants of Ørkenen Sur found solace in the Norwegian Seamen's Church in Brooklyn, which had moved into new and larger premises in $1927 . .^{72}$ They were not alone. By the middle of the $1930 \mathrm{~s}$ there were more than 600 unemployed sailors in Brooklyn, and the

\footnotetext{
${ }^{71}$ In the Norwegian translation of the Bible, the desert in which Moses and the Israelites wander around is called "Sur". The latter word in the text means "sour" or "bitter", and there is thus a dimension that disappears in the English translation. See the fascinating story of the desert and its inhabitants in Gotaas and Kvarsvik (2010).

${ }^{72}$ See Knudsen, 1936, for a contemporary account of the seamen's churches and the mission among seamen.
} 
church also saw a steady stream of seafarers from ships that still traded..$^{73}$ In the church, they would find a reading room, where Tante Klara [Aunt Klara] served waffles that reminded them of their childhoods. ${ }^{74}$ Some would find a letter from home, others would use the free paper and envelopes to write back to Norway. The church was busier than most Norwegian post offices-more than 100,000 letters arrived there every year-it functioned as a bank for some seafarers, and a safe fixed point for even more.

The seamen's churches are a good example of the substantial network that had been developed abroad to serve the country's shipping industry. ${ }^{75}$ The Norwegian Seamen's Church-established in 1864_-provided Norwegian seafarers with a link to the home country when they came to foreign ports. In the beginning the churches were located in the seafarers' "home waters in the Atlantic" - the first one was established in Leith in 1864, while the first location in North America, beginning 12 years later, was in Quebec in the summer and Pensacola in the winter. In 1933 the seamen's church in Shanghai became the first establishment in the Far East. $^{76}$

The churches followed the trade of the Norwegian fleet. In 1927 and 1931, respectively, the churches in Newport and Barry, South Wales, were closed after more than 40 years-there were fewer Norwegian ships

\footnotetext{
${ }^{73}$ Gotaas \& Kvarsvik, 214.

${ }^{74}$ Tante Klara, Klara Breivik, from Fana near Bergen, began working at the Seamen's Church in Brooklyn in 1926 at the age of 20, and helped and supported "her boys" for the subsequent 37 years. She was a "living legend" among the sailors, known for her ability to remember faces and names, her compassion and her skills at couronne [carrom] — the poor man's pool. Another popular "Aunt"-Noel Lowdness in Vancouver-started voluntary work among seamen, before the Scandinavian welfare organizations decided to "employ her" at a fixed fee in the middle of the 1950s. She received the Order of St. Olaf for her work, and after she died in 1977 her ashes were scattered from the Egda, owned by Mowinckels in Bergen; see Pettersen and Brundtland (2003, 79-82).

${ }^{75} \mathrm{~A}$ similar institution was the seamen's homes, operated by Foreningen for skandinaviske sømandshjem i fremmede havne [the Association for Scandinavian Seamen's Homes in Foreign Ports], established 1901 and providing safe sleeping facilities for sober seafarers. See Salvesen (1931) for a contemporary presentation of the Norwegian institutions abroad and their most pressing problems.

${ }^{76}$ There had been activity in Hong Kong and Shanghai for a couple of years during the boom around the Russo-Japanese war 1904-1905, but these were closed when "the market" disappeared a few years later-the number of Norwegian ships calling on Asian ports was more than halved from 1905 to 1907; see Brautaset and Tenold (2010, 207).
} 
involved in the declining coal trade from the area. The increasing oil trade, on the other hand, created a basis for new "business" near oil terminals and refineries. Churches were established in Constanta on the Black Sea in 1935, in Stanford-le-Hope in Essex in 1937, and in Willemstad on the island of Curacao in 1939. By 1939 there were more than 25 Norwegian churches in most parts of the world-in Europe, South and North America, Africa and Asia. ${ }^{77}$ These provided a holier and healthier alternative to Sjappa, the local bar or dive, where alcoholic and corporeal cravings could be satisfied, sometimes at an exorbitant cost in terms of money and health.

The Great Depression affected all types of shipping, even the relatively buoyant tanker market. However, in that sector, the limited number of participants made it possible to arrive at solutions that alleviated individual problems. Effective from the spring of 1934, an international tanker pool ensured that owners with laid-up ships were compensated by those with ships that earned revenues. This solution was the brainchild of Harry T. Schierwater of the United Molasses Company, Ltd., who became the first Chairman of The International Tanker Owners' Association. The pool functioned well due to the participation of the oil companies, which supported the idea in order to ensure orderly conditions in the tanker sector.

While the Norwegian shipping industry regained momentum in the interwar period, helped by yards and finance in Sweden and Denmark, the domestic shipbuilding industry went through a terribly difficult period. In the period 1900-1904 Norway had built more ships than Denmark and Sweden combined, and up until the end of the First World War the production was higher in Norway than in the neighbouring countries. Still, Norwegian shipbuilding peaked in 1915, and then the industry collapsed-in the last five years of the 1930s, production was lower than it had been in the first five years of the century. ${ }^{78}$

\footnotetext{
${ }^{77}$ The churches did not have a presence in Oceania until after the Second World War, and the church in Antarctica (South Georgia) had been closed down after two periods of activity 1912-1914 and 1925-1932; see the overview in Johanson (1989, 113-114). The source confuses "Newport News" and "Newport"; it is quite unlikely that "Newport News" in Virginia, the United States, was operated as a subdivision of the Cardiff branch. On the work of the churches in Belgium and the Netherlands, see Hoel (2016).

${ }^{78}$ Aamundsen (1941, 7-9).
} 
The Danish and Swedish yards managed the transition to motorship building, with a focus on large units, while Norwegian shipyards in the interwar period relied on repair jobs and the increasingly old-fashioned steamship technology. ${ }^{79}$ There are many reasons for the relative decline of Norwegian shipbuilding, compared with its neighbours, in this period. Currency developments and tax policy worked unfavourably, the access to finance and credit might have been more limited than in the the rest of Scandinavia and unfortunate conditions in the labour market and the structure of the industry might have played a role. ${ }^{80}$

Mentioning the relative loss of competitiveness in Norwegian shipbuilding is perhaps a typically gloomy, northern European way of considering the development. In reality, the Scandinavian shipping industry (spearheaded by the Norwegians) and shipbuilding industry (led by the other two countries) developed very positively in a period that was extremely difficult for world shipping and shipbuilding.

The Swedish and Danish expansion was clearly atypical in an international perspective. The global shipbuilding industry was strongly affected by the crisis; in the 1920s, on average, 2.8 million gross tons were launched. In the period 1930-1938, the average was less than 1.8 million gross tons. ${ }^{81}$ Just like the Norwegian expansion within shipping-based on tankers and diesel engines - went against the international trend, the growing role of Swedish and Danish shipyards-partly based on tankers and diesel engines — stood out internationally.

The interwar period was characterized by economic and political turmoil. International trade stagnated, the monetary system collapsed and the attempts at international political cooperation were famously futile. Against this background, the Scandinavian progress is remarkable.

\footnotetext{
${ }^{79}$ In 1927 only 13 ships, amounting to 4838 gross tons were built-less than a tenth of the tonnage built in 1907; based on steel ships in Aamundsen (1941, 117-123). In contrast, the Swedish production in the early 1930s was more than 10 times larger than it had been before the First World War.

${ }^{80}$ See Basberg (1987) for a comparative analysis. An example of the unfortunate conditions in the labour market is the fact that in the period from 1921 to 1931, more than two years' worth of working days were lost due to strikes; Aamundsen $(1941,28)$.

${ }^{81}$ In fact, Norwegian tonnage launches actually expanded marginally from the 1920 s to $1930-1938$, bucking the trend as well. Compared with the growth in Denmark and Sweden, however, the Norwegian increase becomes poor; see the data in Aamundsen $(1941,117)$.
} 


\section{The Sagatind Aftermath}

In March 1938, President Franklin D. Roosevelt recommended to the US Congress that USD5000 be spent to settle a Norwegian claim "arising out of the detention and treatment of the crew" of the Sagatind more than 13 years earlier. ${ }^{82}$ In May the American Congress accepted the payment, "as an act of grace and without reference to the question of legal liability." ${ }^{3}$

When the ex gratia payment was paid out, Sagatind was already history. The ship had to be broken up after running aground in October 1931 near Fedje, outside Bergen on the Norwegian West coast. Sagatind was carrying timber from Archangel in Russia to London in the UK. ${ }^{84}$ Although the loss of the ship marked the end of the shipping company Friis \& Lund, the saga continued in the United States.

The Sagatind compensation was one of the more mundane matters settled in Congress on 13 May 1938. The subsequent piece of legislation that the American politicians approved that day was to establish a national holiday on 11 November, commemorating the day when the First World War ended. The date was "to be dedicated to the cause of world peace and to be hereafter celebrated and known as Armistice Day." ${ }^{55}$

When the first Armistice Day was celebrated, storm clouds were gathering across the sea. Already Norwegian ships had been involved in dangerous and hostile situations in China-for instance during the Japanese bombing of Shanghai-and in the Mediterranean, where the Spanish Civil War affected shipping. On the second Armistice Day, in November

\footnotetext{
${ }^{82}$ The New York Times, 290338, 2.

${ }^{83}$ United States, Parliament, Made into law on 13 May 1938; Public No. 509, Chapter 209; "An act to authorise the payment of an indemnity to the Norwegian Government in full and final satisfaction of all claims based on the detention and treatment of the crew of the Norwegian steamer Sagatind subsequent to the seizure of this vessel by the United States Coast Guard cutter Seneca on 12 October 1924," Laws and concurrent resolutions enacted during the third session of the seventy-fifth Congress of the United States of America, 350.

${ }^{84}$ Thorbjørnsen $(1946,44)$. The cargo was sought after by the locals, and "some salvaged what others had already salvaged before them...”; see Asphaug (2000, 264-265).

${ }^{85}$ Made into law on 13 May 1938; Public No. 509, Chapter 209; "An act making the 11th day of November each year into a legal holiday," Laws and concurrent resolutions enacted during the third session of the seventy-fifth Congress of the United States of America, 351.
} 
1939, things were far more serious. The major powers in Europe were again at war.

In the first months of the war, Norway remained neutral, and the situation was not radically different from the case during the previous world war. The Norwegian fleet was once again vulnerable, and an important asset in the fight among the big powers. This time, however, Norway did not remain neutral for long. After the German invasion on 9 April 1940, Norwegian shipping entered its toughest—and also most heroic- - hour.

\section{Bibliography}

L. Albretsen (1942) 'Litt om radio', in O.T. Irgens, Et lite skippertak (Bergen: AS John Griegs Boktrykkeri) 64-87

H.W. Andersen (1992) 'Laggards as Leaders: Some Reflections on Technological Diffusion in Norwegian Shipping', in K. Bruland, Kristine (ed) Technology Transfer and Scandinavian Industrialization (Oxford: Berg)

A. Asphaug (2000) Øygarden 1920-1958 - Aktive fiskarbøndar, travle gardskoner, Vol. 1 (Tjeldstø: Øygarden Kommune)

D. Bakka (1998) O.H. Meling \& Co. Femti år i shipping (Stavanger: O.H. Meling)

D. Bakka (2008) Linjer rundt Jorden - Historien om norsk linjefart (Bergen: Seagull Publishing)

B.L. Basberg (1987) 'Motortankskipenes inntog. En komparasjon av utviklingen i dansk, norsk og svensk skipsbyggingsindustri, ca. 1912 til 1933', Sjøfartshistorisk Årbok 1986 (Bergen: Bergens Sjøfartsmuseum)

B.L. Basberg (2006) 'Perspectives on the Economic History of the Antarctic Region', International Journal of Maritime History, 18:2, 185-304

E. Behr, (1996) Prohibition: Thirteen Years That Changed America (New York: Arcade Publishing)

P. Bolle (2006) 'The ILO's New Convention on Maritime Labour: An Innovation Instrument', International Labour Review, 145:1-2, 135-142

J. Bohlin (1989) Svensk varvsindustri 1920-1975: Lönsambet, finansiering och arbetsmarknad (Gothenburg: Ekonomisk-historiska institutionen vid Göteborgs Universitet)

C. Brautaset \& S. Tenold (2010) 'Lost in Calculation? Norwegian Merchant Shipping in Asia, 1870-1914', in M. Fusaro \& A. Polónia (eds) Maritime History as Global History (St. Johns: IMEHA) 203-222 
J. Bruijn, (2005) 'Seafarers in Early Modern and Modern Times: Change and Continuity', The International Journal of Maritime History, 17:1, 1-16

K. Brækhus (1955) Trampskipsfartens fremtid (Oslo: Norges Rederforbund)

R. Carlisle (2009) 'Second Registers: Maritime Nations Respond to Flags of Convenience, 1984-1998', The Northern Marinerlle marin du nord, 19:3, 319-340

R. Carlisle (2017) Rough waters: Sovereignty and the American merchant flag (Annapolis: Naval Institute Press)

R.B. Castelein, (2015) 'The Fairplay freights: compiling a dataset of interwar freight rates', The International Journal of Maritime History, 27:2, 302-327

T. Chida \& P.N. Davies (1990) The Japanese Shipping and Shipbuilding Industries: A History of their Modern Growth (London: Athlone Press)

C. Christensen (1933) Det hendte i går: En skildring av etterkrigstidens Norge (Oslo: Johan Grundt Tanum)

H.I. Drevdal (1994) Fra de hvite seils dager: beretninger og minner om menn og deres skip (Grimstad: Drevdal)

J.O. Egeland (1930) 'Norges sjøfart. Hvad den var og hvad den er', in G. Stenersen (ed) Sjømannsboken; sjøfart, hvalfangst, marine: orientering i sjømannskap, veiledning til selvstudium, (Oslo: Norsk bibliotekforening) 3-37

J.O. Egeland (1973) Kongeveien, Volume II (Oslo: H. Aschehoug \& Co.)

J. Einarsen (1938) Reinvestment cycles and their manifestation in the Norwegian shipping industry (Oslo: J. Chr. Gundersens Boktrykkeri)

K. Fasting (1955) AS Moltzaus Tankrederi (Oslo: AS Moltzaus Tankrederi)

L. Fink (2016) 'A Sea of Difference: The ILO and the Search for Common Standards, 1919-45', in J.M. Jensen \& N. Lichtenstein (eds) The ILO from Geneva to the Pacific Rim (London: Palgrave Macmillan) 15-32

A. Gibson \& A. Donovan (2001) The Abandoned Ocean: A HIstory of the United States Maritime Policy (Columbia: University of South Carolina Press)

E. Gjermoe (1964) Kurser og dividender for skipsaksjeselskaper på Bergens børs 1929-1964 (Bergen: Skipsfartsøkonomisk Institutt)

T. Gotaas \& R. Kvarsvik (2010) Ørkenen Sur (Oslo: Spartacus)

O.H. Grytten (1994) 'En empirisk analyse av det norske arbeidsmarked 1918-1939’, PhD-thesis, Bergen: Norges Handelshøyskole

O.H. Grytten (2004) 'A consumer price index for Norway 1516-2003', in Ø. Eitrheim, J.T. Klovland \& J.F. Qvigstad (eds) Historical Monetary Statistics for Norway 1819-2003 (Oslo: Norges Bank) 47-98

J. Gunnerud (1992) 'Tankskipseventyret i Oslo 1925-1939', Sjøfartshistorisk Årbok 1991 (Bergen: Bergens Sjøfartsmuseum) 
M. Hammerborg (2011) 'Inheriting Strategies: Understanding Different Approaches to Shipping During the World War I Boom in Haugesund, Norway', in L.R. Fischer \& E. Lange (eds) New directions in Norwegian maritime history (St. Johns: IMEHA)

G. Harlaftis (1996) A History of Greek-Owned Shipping: The Making of an International Tramp Fleet, 1830 to the present day (Abingdon: Routledge)

G. Harlaftis \& I. Theotokas (2004) 'European Family Firms in International Business: British and Greek Tramp-Shipping Firms', Business History, 46:2, 219-255

V. Hoel (2016) Faith, Fatherland and the Norwegian Seaman (Hilvershum: Verloren Publishers)

C. Haaland (1940) Norges skipsfart - hva den var og hva den er (Oslo: Blix Forlag AS)

P.E. Johansen (1994) Markedet som ikke ville dø: forbudstiden og de illegale alkoholmarkedene i Norge og USA (Oslo: Rusmiddeldirektoratet)

B. Johanson (1989) Kirke i verdens hverdag (Bergen: Den norske sjømannsmisjons forlag)

G. Kåhre (1977) The Last Tall Ships: Gustaf Erikson and the Aland Sailing Fleets, 1872-1947 (New York: Mayflower Books)

G. Kåhre (1980) De siste seilskip i handelsfart: Gustaf Erikson og Ålands handelsflàte 1872-1947 (Oslo: Schibsted)

C. Kent (1925) Under norsk flag (Oslo: H. Aschehoug \& Co.)

K.U. Kloster (1935) Krigsår og gullflom - Skibsfarten under verdenskrigen (Oslo: Gyldendal)

R. Kloster (1942) 'Omkring kostholdet til sjøs', in O.T. Irgens, Et lite skippertak (Bergen: AS John Griegs Boktrykkeri) 64-87

J.T. Klovland (2016) 'Shipping in dire straits: New evidence on trends and cycles in coal freights from Britain, 1919-1939', Discussion paper SAM 05/2016 (Bergen: NHH - Norwegian School of Economics)

J.T. Klovland (2017) 'Navigating through torpedo attacks and enemy raiders: Merchant shipping and freight rates during World War I', Discussion paper SAM 07/2017 (Bergen: NHH - Norwegian School of Economics)

B. Kolltveit (1977) Skippere Meglere Redere (Oslo: J.M. Stenersens Forlag AS)

J.A. Langfeldt (1980) Et liv i shipping (Kristiansand: J.A. Langfeldt)

E.N. Lawson (2013) Smugglers, Bootleggers and Scofflaws. Prohibition and New York City (Albany: State University of New York Press)

N. Livingstone (2016) The Mistresses of Cliveden: Three Centuries of Scandal, Power, and Intrigue in an English Stately Home (London: Arrow) 
Lombard (1934) Lombard Shipping and Transport Code (London: Code Services Ltd.)

K. Magnus (1942) 'Nogen forskyvninger innen norsk skipsfart', in O.T. Irgens Et lite skippertak (Bergen: AS John Griegs Boktrykkeri) 88-101

N.L. Middlemiss (1996) World Tankers (Newcastle: Shield Publications Ltd.)

G.R. Mohn (1942) 'Navigasjonsundervisningens utvikling i de siste 25 år', in

O.T. Irgens, Et lite skippertak (Bergen: AS John Griegs Boktrykkeri) 64-87

E. Newby (1956) The last grain race (London: Secker \& Warburg)

E.D. Næss (1977) Autobiography of a Shipping Man (Seatrade, London)

E.D. Næss (1981) Shipping - mitt liv (Oslo: AS Hjemmet Fagpresseforlaget)

E. Pettersen \& H. Brundtland (2003) Sjøfolkenes hemmeligheter-opplevelser fra handelsflàten i etterkrigstiden (Bergen: Edvard'en Forlag)

T. Salvesen (1931) Havnebyer. Internasjonalt samarbeide til bedring av sjømenns livsvilkair i land (Oslo: H. Aschehoug \& Co.)

J. Schreiner (1963) Norsk skipsfart under krig og høykonjunktur, 1914-1920 (Oslo: Norges Rederforbund/Cappelen)

P.K. Sebak (2011) 'The Norwegian-American Line: State Incentives and Mediations with Dominant Market Players', in L.R. Fischer \& E. Lange (eds) New directions in Norwegian maritime history (St. Johns: IMEHA)

J. Seland (1953) Oversikt over momenter som kan belyse utviklingen i àrene fremover av verdenshandelen, verdensflàten og Norges flàte samt over de norske skattereglers virkning for skipsfartsnaringen og andre lands skatteregler (Oslo: Norges Rederforbund)

J. Seland (1959) Rederen og skipet. Kristiansand og Mandal fra seil til damp og diesel (Kristiansand: Christiansands Rederforening)

Statistics Norway (1902) Statistisk aarbog for kongeriget Norge 1902 (Kristiania: Det Statistiske Centralbureau/H. Aschehoug \& Co.)

Statistics Norway (1919) Statistisk aarbok for kongeriket Norge 1919 (Kristiania: Det Statistiske Centralbyrå/H. Aschehoug \& Co.)

Statistics Norway (1929) Statistisk aarbog for kongeriget Norge 1929 (Kristiania: Det Statistiske Centralbureau/H. Aschehoug \& Co.)

Statistics Norway (1939) Statistisk aarbog for kongeriget Norge 1939 (Kristiania: Det Statistiske Centralbureau/H. Aschehoug \& Co.)

Statistics Norway (1948) Statistiske oversikter 1948 (Oslo: Statistiske Sentralbyrå) Statistics Norway (1968) Historisk Statistikk 1968 (Oslo: Statistisk Sentralbyrå) S.G. Sturmey (1962) British Shipping and World Competition, reprint 2010 (St. Johns: IMEHA)

S. Tenold (2006) 'Crisis? What Crisis?', in L.U. Scholl \& D.M. Williams (eds) Crisis and Transition. Maritime Sectors in the North Sea Region 1790-1940 (Bremen: Verlag H.M. Hauschild, GmbH.) 117-134 
S. Tenold (2007) 'Norway's Interwar Tanker Expansion - A Reappraisal', Scandinavian Economic History Review, 55:3, 244-261

K. Thorbjørnsen (1946) Av bjergningsvesenets historie - Norsk Bjergningskompani AS, Havarifortegnelser, 1912-1938, Vol. 3B (Bergen: Norsk Bjergningskompani AS)

A. Thowsen (1983) 'Vekst og strukturendringer i krisetider 1914-1939', Bergen og Sjøfarten IV (Bergen: Bergens Rederiforening og Bergens Sjøfartsmuseum)

A. Thowsen (1992) 'Nortraship - Profitt og Patriotisme', Handelsflàten i krig 1 (Oslo: Grøndahl og Dreyers Forlag AS)

J.N. Tønnessen (1951) 'Fra klipperen til motorskipet', in J.S. Worm-Müller (ed) Den norske sjøfarts historie: Fra de aldste tider til vore dager, 2:3 (Oslo: J.W. Cappelens Forlag) 1-222

J.N. Tønnessen \& A.O. Johnsen (1982) The history of modern whaling (Berkeley and Los Angeles: University of California Press)

N.P. Vigeland (1949) Norsk seilskipsfart erobrer verdenshavene (Trondheim: E. Bruns Bokhandels Forlag)

T.R. Aamundsen (1941) Reisningen av den norske skipsbygginsindustri (Oslo: Gunnar Stenersens Forlag)

Open Access This chapter is licensed under the terms of the Creative Commons Attribution-NonCommercial-NoDerivatives 4.0 International License (http:// creativecommons.org/licenses/by-nc-nd/4.0/), which permits any noncommercial use, sharing, distribution and reproduction in any medium or format, as long as you give appropriate credit to the original author(s) and the source, provide a link to the Creative Commons license and indicate if you modified the licensed material. You do not have permission under this license to share adapted material derived from this chapter or parts of it.

The images or other third party material in this chapter are included in the chapter's Creative Commons license, unless indicated otherwise in a credit line to the material. If material is not included in the chapter's Creative Commons license and your intended use is not permitted by statutory regulation or exceeds the permitted use, you will need to obtain permission directly from the copyright holder.

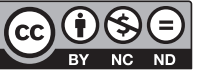

